\title{
Influence of rs1137101 gene polymorphism of leptin receptor on the development of diabetes mellitus type 2 and obesity
}

\author{
S.V. Ziablitsev ${ }^{1}$, T.U. Uzvenko ${ }^{2}$, O.P. Chernobrivtsev ${ }^{1}$, A.A. Grishov ${ }^{1}$, S. Palamar ${ }^{1}$, \\ D.S. Ziablitsev ${ }^{1}$ \\ ${ }^{1}$ Bogomolets National Medical University, Kiev, Ukraine; e-mail: zsv1965@gmail.com; \\ ${ }^{2}$ Ukrainian Research and Practical Centre of Endocrine Surgery, Transplantation of Endocrine Organs \\ and Tissues of the Ministry of Health of Ukraine, Kiev, Ukraine
}

\begin{abstract}
The aim of this research was a study of gene LEPR polymorphism rs 1137101 role in diabetes mellitus 2 type development and his influences on the clinical and laboratory data, related to obesity for these patients. 103 patients are inspected, that had the clinically expressed complications. A control group was made by 100 practically healthy persons of corresponding age. The analysis of polymorphic DNA-loci was carried out by the method of polymerase chain reaction in real time (TaqMan ${ }^{\circledR} S N P$ Genotyping Assay). Results showed that allelic polymorphism of rs 1137101 (223Gln $>$ Arg) had been associated with diabetes mellitus 2 types development: allele Gln promotes, while allele Arg - reduces $(O R=1.5 ; P=0.039)$ the risk of its development. Presence allele Gln for diabetic patients assists development of obesity and his displays, namely - to the higher values of body mass index and HOMA-IR, and also to the greater leptin and triglycerides blood levels on a background reduction of high-density lipoproteides maintenance. The risk of developing obesity in these patients is increased by 1.8 times.
\end{abstract}

Key words: diabetes mellitus 2 types; leptin receptor gene; rs 1137101.

\section{INTRODUCTION}

Despite the adoption of national programs for the control of diabetes in most countries of the world, its prevalence and morbidity continue to increase, mainly due to diabetes mellitus type 2 (DM2) [1]. Comparable trend is typical for Ukraine, where today more than 1.3 million patients are counted. In fact, these data are substantially understated, since over $50 \%$ of patients with DM2, with pre-diabetes and the latent course of the disease remain undiagnosed [2].

It was established that the main link of the pathogenesis of DM2 is chronic hyperglycemia, which develops on background of insulin resistance and progressive functional activity decreament of $\beta$-cells of the pancreas $[3,4]$. In this setting, in most cases, DM2 is combined with abdominal-visceral obesity [1, 2], and has a dependence on some genetic polymorphisms
[10]. It is shown that the degree of obesity directly affects the rate of development, and, accordingly, the severity of hyperglycemia and cardiovascular complications, which are one of main causes of early disability and high mortality of patients [1].

Key role in the regulation of lipogenesis and oxidation of fatty acids is given to leptin, which, being integrated into the feedback system with the participation of hypothalamic neuropeptides, participates in the system of regulation of hunger and satiation. It was established that, in case of DM2 phenomenon of leptin resistance develops, in which hyperleptinemia, that directly depends on amount of adipose tissue, is accompanied by loss of the physiological properties of the hormone. Leptin resistance contributes significantly to the formation and progression of obesity, angiopathy and insulin resistance $[3,4]$.

(C) S.V. Ziablitsev, T.U. Uzvenko, O.P. Chernobrivtsev, A.A. Grishov, S. Palamar, D.S. Ziablitsev 
Some causes of leptin sensibility loss are described. Among them leading role is issued to disorders of structure of specific receptors LepRa-LepRf which are present in the hypothalamus, peripheral organs and tissues (fat, liver, skeletal muscles, pancreas, testicles, prostate, placenta, kidneys, lungs) and are coded by the gene LEPR (chromosomal localization 1p31, exon 24) $[3,6]$. Product of this gene protein gp130 belongs to the family of cytokine receptors, which stimulate transcription of genes through activation of cytosol proteins STAT [6]. Some $L E P R$ polymorphisms are described, but rs 1137101 is the most investigated among them. The point of single-nucleotide polymorphism is change of adenine $(A)$ for guanine $(G)$ in the position 668 of the gene $(668 A>G)$, that leads to change of glutamine for arginine in the 223rd position of protein receptor (Gln223 Arg) [7]. Research results, which are dedicated to influence of $r s 1137101$ polymorphism of $L E P R$ gene to the development of DM2 are contradictory and in Ukrainian population are not defined at all.

The aim of the study is to define role of rs 1137101 polymorphism of LEPR gene in the pathogenesis of the DM2 and its influence on clinical laboratory indices which are connected with obesity among patients with the DM2.

\section{METHODS}

Data from 103 patients with DM2, that had clinically apparent complications of main illness, were investigated. The age of patients was from 33 to 79 years, mean age $53 \pm 8$ years. 38 were men $(37 \%), 65$ - women $(63 \%)$. All patients had complications like diabetic polyneuropathies (88\%), microangiopathies (84\%), ophtalmopathies $(40 \%)$, encephalopathies (27\%), and nephropathies (20\%). Durations of disease were from 1 to 25 years. $23 \%$ of patients had close relatives with DM2. Control group consisted from 100 healthy people with according age and sex distribution.
Analysis of polymorphous DNA-locuses was performed by method of polymerase chain reaction $(\mathrm{PCR})$ in real-time with use of TaqMan ${ }^{\circledR}$ SNP Genotyping Assay system (USA) on the amplificatory Applied Biosystems 7500 RealTime PCR System (USA). Blood biochemical parameters of lipid metabolism were evaluated with spectrophotometry, body mass index (BMI) and insulin resistance index (HOMA) were also calculated. Influence of polymorphic markers on the development of disease was evaluated with ANOVA and contingency tables. Degree of disease association was evaluated with odd ratio calculation. Statistical calculations were performed in Statistica 10 application program (StatSoft, Inc, USA).

\section{RESULTS AND DISCUSSION}

Frequencies of genotypes of rs 1137101 polymorphism of $L E P R$ gene in the experimental and control groups were distributed in the following way (Fig. 1): Gln/Gln - 0.282 and 0.170; Gln/ Arg - 0.582 and 0.600; Arg/Arg - 0.136 and 0.230 .

Analysis of genotype frequencies revealed significant increase ( 1.65 fold; $\mathrm{P}=0.041$ ) of Gln/Gln genotype in the experimental group in comparison with control group. Other genotypes frequencies did not differ significantly. Need to be said, that received data corresponded with the Hardy-Weinberg equation for cases $\left(\chi^{2}=3.730\right.$,

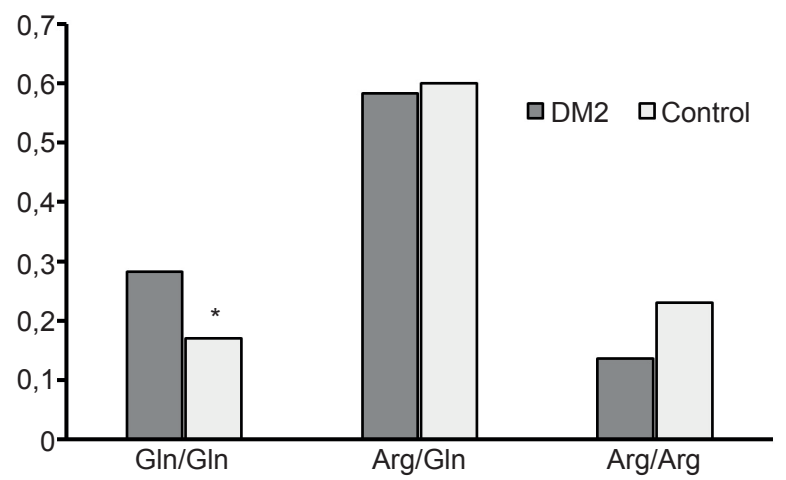

Fig. 1. Frequencies of genotypes of $r s 1137101$ polymorphism of $L E P R$ gene.

* difference is statistically significant (F-test, $\mathrm{P}=0.041$ ) 
$\mathrm{df}=1, \mathrm{P}=0.162)$ and controls $\left(\chi^{2}=4.175, \mathrm{df}=1\right.$, $\mathrm{P}=0.129)$. Allelic frequencies of rs 1137101 polymorphism of $L E P R$ gene were distributed in experimental and control groups in accordance: Gln -0.573 and 0.470 ; Arg -0.427 and 0.530 (Fig. 2).

The analysis of contingency tables $(3 \times 2)$ didn't show significant association of genotypes of $r s 1137101$ polymorphism of LEPR gene with DM2 development in both groups: $\chi^{2}=5.276$; $\mathrm{df}=2 ; \mathrm{P}=0.074$ (Table 1).

Significant association between allele Gln and the presence of DM2 was revealed by analysis of influence of alleles of rs 1137101 polymorphism of $L E P R$ gene on the development of DM2 by $2 \times 2$ tables: $\chi^{2}=4.299$; $d f=1$; $\mathrm{P}=0.039$ (Table 2).

It was revealed, that carriers of Gln allele had 1.5 times higher degree of association with DM2 (OR=1.512; CI 1.022-2.237; $\mathrm{P}=0.039)$. In case of presence of Arg allele degree of association with DM2 was 1.5 times lower.

ANOVA showed influence of Gln allele of rs 1137101 polymorphism of LEPR gene (Table 3 ) to higher BMI in comparison to Arg allele $\left(26.29 \pm 0.81 \mathrm{~kg} / \mathrm{m}^{2}\right.$ and $30.32 \pm 0.68 \mathrm{~kg} /$ $\left.\mathrm{m}^{2} ; \mathrm{F}=7.51 ; \mathrm{P}=0.003\right)$; higher blood leptin concentration $(87.27 \pm 7.52 \mathrm{ng} / \mathrm{ml}$ and $105.58 \pm$ $10.25 \mathrm{ng} / \mathrm{ml} ; \mathrm{F}=6.59 ; \mathrm{P}=0.006)$; higher level of triglyceride $(4.48 \pm 0.41 \mathrm{mmol} / \mathrm{L}$ and $5.52 \pm 0.48 \mathrm{mmol} / \mathrm{L} ; \mathrm{F}=5.27 ; \mathrm{P}=0.015)$; and

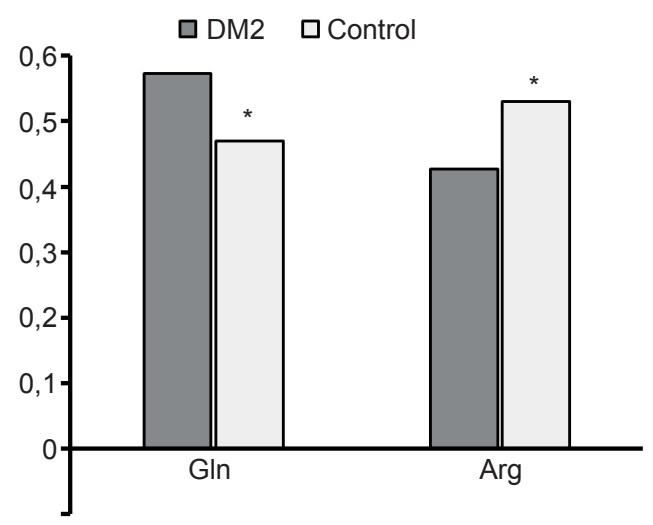

Fig. 2. Frequencies of alleles of rs 1137101 polymorphism of LEPR gene.

* difference is statistically significant $(\mathrm{F}$-test, $\mathrm{P}=0.024)$ higher HOMA (7.66 \pm 0.75 and 9.47 \pm 0.99 ; $\mathrm{F}=3.64 ; \mathrm{P}=0.040)$; and decrease of highdensity lipoprotein (HDL) blood concentration $(2.01 \pm 0.09 \mathrm{mmol} / \mathrm{L}$ and $1.57 \pm 0.11 \mathrm{mmol} / \mathrm{L}$; $\mathrm{F}=4.90 ; \mathrm{P}=0.019$ ).

Listed changes are traditionally linked with obesity in patients with DM2 [8,9] and presented in the table 3 according to decrease of influence degree of alleles of rs1137101 polymorphism of $L E P R$ gene: increase of BMI $>$ hyperleptinemia $>$ dyslipidemia (increase of triglycerides and decrease of protective HDL), which were on the background of increase of insulin resistance.

Numeral data [8-10] shows that rs 1137101 polymorphism of $L E P R$ gene leads to disorder of structure and function of leptin receptor and blocks its expression with alteration of hormonal signal. We suggest that presence of allele Gln in genotype contributes increase of BMI, HOMO, leptin and triglyceride level, and decrease protective HDL.

For evaluation of influence of $r s 1137101$ polymorphism of $L E P R$ gene on obesity in patients with DM2 the distribution of genotypes and alleles was analyzed in cases, where BMI $>30 \mathrm{~kg} / \mathrm{m}^{2}$ (obesity) and $\mathrm{BMI} \leq 30 \mathrm{~kg} / \mathrm{m}^{2}$ (normal weight and overweight). As it shown in the table 4 obesity patients with DM2 had 2 times higher frequency of Gln223Gln genotype than patients without obesity $(36.5 \%$ and $19.6 \%$ respectively, $\mathrm{P}=0.045$ ).

Frequencies of heterozygous genotype Gln223Arg didn't differ significantly and frequency of the minor homozygous genotype Arg223Arg in pathients with obesity was 2.5 times rarely $(7.7 \%$ against $19.6 \%$ in patients without obesity; $\mathrm{P}=0.025$ ). Dependence of distribution of genotypes from presence or absence of obesity was not revealed $(\mathrm{P}=0.069)$ on condition of accordance of data in groups by BMI to the Hardy-Weinberg equation $\left(\chi^{2}=2.404\right.$; $\mathrm{df}=1$; $\mathrm{P}=0.308$ for group with $\mathrm{BMI}>30$ and $\chi^{2}=2.373$; $\mathrm{df}=1, \mathrm{P}=0.319$ for group with $\mathrm{BMI} \leq 30$ ).

There was significant difference between groups with different BMI by frequency of 
Table 1. Influence of genotypes of $r s 1137101$ polymorphism of $L E P R$ gene on the development of DM2; odds ratio $(\mathrm{CI}=95 \%)$

\begin{tabular}{lcccccccc|}
\hline Genotypes & DM2 $(\mathrm{n}=103)$ & Control $(\mathrm{n}=100)$ & OR & CI $-95 \%$ & $\chi^{2}$ & $\mathrm{p}$ \\
\hline Gln/Gln & 29 & 17 & 1.913 & $0.973-3.761$ & & \\
Gln/Arg & 60 & 60 & 0.930 & $0.531-1.628$ & 5.276 & 0.074 \\
Arg/Arg & 14 & 23 & 0.527 & $0.254-1.094$ & & \\
\hline
\end{tabular}

alleles of $r_{S} 1137101$ polymorphism of $L E P R$ gene. In the group with BMI $>30$ allele 223Gln was present in $64.4 \%$ cases and in the group with BMI $\leq 30-$ in $50 \%$ of cases. For allele 223 Arg distribution was opposite: group with $\mathrm{BMI}>30-35.6 \%$, group with $\mathrm{BMI} \leq 30-50 \%$ $(\mathrm{P}=0.038)$. In presence of obesity in patients with DM2 223Gln allele occurred 1.3 times more and minor $223 \mathrm{Arg}$ allele 1.4 times rarely.
Thereby we suggest that $223 \mathrm{Gln}$ allele is associated with obesity (BMI $>30)$ in DM2 and risk of obesity development is 1.8 times increased ( $\mathrm{OR}=1.811$; CI 1.036-3.165; $\mathrm{P}=0.038)$.

Thus $r$ s 1137101 polymorphism (223Gln $>$ Arg) of $L E P R$ gene is a risk factor for DM2 and contributes to obesity in these patients. DM2 could be related to diseases with inherited predisposition which has high risk of development in per-

Table 2. Influence of alleles of $r s 1137101$ polymorphism of $L E P R$ gene to the development of DM2; odds ratio (CI=95\%)

\begin{tabular}{l|ccccccc|c|}
\hline Alleles & DM2 $(\mathrm{n}=206)$ & Control $(\mathrm{n}=200)$ & OR & CI $-95 \%$ & $\chi^{2}$ & $\mathrm{p}$ \\
\hline Gln & 118 & 94 & 1.512 & $1.022-2.237$ & \multirow{2}{*}{4.299} & 0.039 \\
Arg & 88 & 106 & 0.661 & $0.447-0.978$ & & \\
\hline
\end{tabular}

sons with respective $r s 1137101$ polymorphism of $L E P R$ gene according to multiplicative model of inheritance under the provocative influence of modified risk factors.

\section{CONCLUSION}

Higher rate of Gln/Gln genotype was revealed in patients with DM2 in comparison to the control group (1.65 times more; $\mathrm{P}=0.041$ ).

Gln allele was present more often and Arg allele - more rarely in patients with DM2
(1.2 times in comparison to the control group; $\mathrm{P}=0.024)$. Carriers of Gln allele had 1.5 times higher risk of DM2 development and presence of Arg allele - 1.5 times lower risk of disease $(\mathrm{P}=0.039)$.

Presence of Gln allele in patients with DM2 contributes to progression of obesity and insulin resistance, more pronounced hyperleptinemia and dyslipidemia (increase of triglyceride and decrease of HDL). The risk of obesity development was 1.8 times higher among these patients.

Table 3. Indexes with significant influence of alleles of $r s 1137101$ polymorphism of $L E P R$ gene

\begin{tabular}{|c|c|c|c|c|}
\hline \multirow{2}{*}{ Index } & \multicolumn{2}{|c|}{ Allele } & \multirow{2}{*}{$\mathrm{F}$} & \multirow{2}{*}{$\mathrm{P}$} \\
\hline & Gln & Arg & & \\
\hline BMI, $\mathrm{kg} / \mathrm{m}^{2}$ & $30.32 \pm 0.68$ & $26.29 \pm 0.81$ & 7.51 & 0.003 \\
\hline Leptin, ng/ml & $105.58 \pm 10.25$ & $87.27 \pm 7.52$ & 6.59 & 0.006 \\
\hline Triglyceride, $\mathrm{mmol} / \mathrm{L}$ & $5.52 \pm 0.48$ & $4.48 \pm 0.41$ & 5.27 & 0.015 \\
\hline $\mathrm{HDL}, \mathrm{mmol} / \mathrm{L}$ & $1.57 \pm 0.11$ & $2.01 \pm 0.09$ & 4.90 & 0.019 \\
\hline HOMA & $9.47 \pm 0.99$ & $7.66 \pm 0.75$ & 3.64 & 0.040 \\
\hline
\end{tabular}


Table 4. Influence of genotypes and alleles of $r s 1137101$ polymorphism of $L E P R$ gene to the development of obesity in DM2

\begin{tabular}{l|c|c|c|c|c|c|}
\hline \multicolumn{1}{|c|}{ Genotype } & $\begin{array}{c}\text { BMI }>30(\mathrm{n}=52) \\
\mathrm{n} / \%\end{array}$ & $\begin{array}{c}\text { BMI } \leq 30(\mathrm{n}=51) \\
\mathrm{n} / \%\end{array}$ & OR & CI $-95 \%$ & $\chi^{2}$ & P \\
\hline Gln/Gln & $19 / 36.5$ & $10 / 19.6$ & 2.361 & $0.967-5.762$ & & \\
Gln/Arg & $29 / 55.8$ & $31 / 60.8$ & 0.813 & $0.371-1.783$ & 5.422 & 0.069 \\
Arg/Arg & $4 / 7.70$ & $10 / 19.6$ & 0.342 & $0.100-1.171$ & & \\
Gln & $67 / 64.4$ & $51 / 50.0$ & 1.811 & $1.036-3.165$ & & \\
Arg & $37 / 35.6$ & $51 / 50.0$ & 0.552 & $0.316-0.965$ & 4.378 & 0.038 \\
\hline
\end{tabular}

The authors of this study confirm that the research and publication of the results were not associated with any conflicts regarding commercial or financial relations, relations with organizations and/or individuals who may have been related to the study, and interrelations of coauthors of the article.

\section{С. В. Зябліцев, Т. Ю. Юзвенко,}

О. П. Чернобривцев, А. А. Грішов, С. Паламар, Д.С. Зябліщев

\section{ВПЛИВ ПОЛІМОРФІЗМУ RS1137101 ГЕНА РЕЦЕПТОРА ЛЕПТИНУ НА РОЗВИТОК ЦУКРОВОГО ДІАБЕТУ 2-ГО ТИПУ ТА ОЖИРІННЯ}

Вивчали роль поліморфізму rs1137101 гена LEPR у розвитку цукрового діабету (ЦД) 2-го типу і його впливу на клініко-лабораторні показники, пов'язані з ожирінням у цих хворих. Обстежено пацієнтів $(\mathrm{n}=103) 3$ таким діагнозом, які мали клінічно виражені ускладнення. Контрольну групи склали 100 практично здорових осіб відповідного віку. Аналіз поліморфних ДНК-локусів здійснювали методом полімеразної ланцюгової реакції у реальному часі (TaqMan ${ }^{\circledR}$ SNP Genotyping Assay). Peзультати показали, що алельний поліморфізм rs1137101 (223Gln $>\operatorname{Arg}$ ) був асоційований з розвитком цукрового діабету 2-го типу: алель Gln його підвищує, а алель Arg знижує $(\mathrm{OR}=1,5 ; \mathrm{P}=0,039)$ ризик його розвитку. Наявність алелі Gln у хворих на діабет сприяє розвитку ожиріння та його проявів, а саме - більш високим значенням індексу маси тіла та індексу інсулінорезистентності, а також більшому вмісту у крові лептину та тригліцеридів на тлі зменшення вмісту ліпопротеїдів високої щільності. Ризик розвитку ожиріння у таких хворих підвищено у 1,8 раза. Ключові слова: цукровий діабет 2-го типу; ген рецептора лептину; rs1137101.

${ }^{1}$ Bogomolets National Medical University, Kiev, Ukraine; e-mail:zsv1965@gmail.com
${ }^{2}$ Ukrainian Research and Practical Centre of Endocrine Surgery, Transplantation of Endocrine Organs and Tissues of the Ministry of Health of Ukraine, Kiev, Ukraine

\section{С. В. Зяблицев, Т. Ю. Юзвенко,}

А. П. Чернобривцев, А. А. Гришов, С. Паламар, Д.С. Зяблицев

\section{ВЛИЯНИЕ ПОЛИМОРФИЗМА RS1137101 ГЕНА РЕЦЕПТОРА ЛЕПТИНА НА РАЗВИТИЕ САХАРНОГО ДИАБЕТА 2 ТИПА И ОЖИРЕНИЯ}

Исследовали роль полиморфизма rs1137101 гена LEPR в развитии сахарного диабета 2-го типа и его влияния на клинико-лабораторные показатели, связанные с ожирением у этих больных. Обследовано 103 пациента, которые имели клинически выраженные осложнения. Контрольную группу составили 100 практически здоровых человек соответствующего возраста. Анализ полиморфных ДНК-локусов осуществляли методом полимеразной цепной реакции в реальном времени (TaqMan ${ }^{\circledR}$ SNP Genotyping Assay). Результаты показали, что аллельный полиморфизм rs1137101 (223Gln>Arg) был ассоциирован с развитием сахарного диабета 2-го типа: аллель Gln его повышает, а алель Arg - снижает $(\mathrm{OR}=1,5 ; \mathrm{P}=0,039)$. Наличие аллели Gln у больных c диабетом способствует развитию ожирения и его проявлений, а именно - более высоким значениям индекса массы тела и индекса инсулинорезистентности, а также большему уровню в крови лептина и триглицеридов на фоне уменьшения содержания липопротеидов высокой плотности. Риск развития ожирения у этих больных повышен в 1,8 раза.

Ключевые слова: сахарный диабет 2-го типа; ген рецептора лептина; rs1137101.

\section{REFERENCES}

1. Global status report on noncommunicable diseases. 2014. Geneva: WHO, 2014.

2. Mankovskyy BN. Incidence of non-revealed diabetes 
mellitus type 2 and pre-diabetes in Ukraine: results of the epidemiological investigation "Diapazon". Diabetes Obesity Metabolic Syndrome. 2014; 3(5): 70-5. [Ukrainian].

3. Fantuzzi G. Adipose tissue, adipokines, and inflammation. J. Allergy Clin Immunol. 2006; 115(5): 911-9.

4. Dedov II, Balabolkin MI, Mamaeva GG. Insulin resistance and role of hormones of fat tissue in the development of diabetes mellitus. Moscow. 2005. [Russian].

5. Ziablitsev SV, Mokrii VY, Cristal MV. The value of polimorfism Pro12Ala gene in violation of lipid peroxidation and antioxidant protection in patient with type 2 diabetes mellitus. J Education, Health and Sport formely of Health Sci. 2016; 6(9): 626-36.

6. Münzberg H, Morrison CD. Structure, production and signaling of leptin. Metabolism. 2015; 64(1): 13-23.
7. Sun Q, Cornelis MC, Kraft P. Genome-wide association study identifies polymorphisms in LEPR as determinants of plasma soluble leptin receptor levels. Human Molecular Genetics. 2010; 19(9): 1846-55.

8. Jiang B, Liu Y, Liu Y, Fang F, Wang X, Li B. Association of four insulin resistance genes with type 2 diabetes mellitus and hypertension in the Chinese Han population. Mol Biol Rep. 2014; 41(2): 925-33.

9. Queiroz EM, Cândido APC, Castro IM. IGF2, LEPR, POMC, PPARG, and PPARGC1 gene variants are associated with obesity-related risk phenotypes in Brazilian children and adolescents. Braz J Med Biol Res. 2015; 48(7): 595-602.

10. Stratigopoulos G, LeDuc ChA, Matsuoka N. Functional consequences of the human leptin receptor (LEPR) Q223R transversion. Obesity. 2009; 17(1): 126-35.

Received 12.07.18 